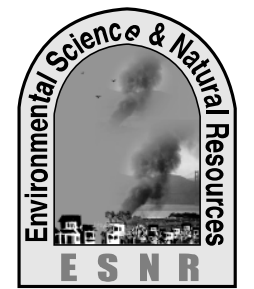

\title{
Improvement of Salt Tolerance in Maize by Exogenous Application of Proline
}

\author{
M. I. Hasan, M. G. Kibria, M. Jahiruddin, Y. Murata ${ }^{1}$ and M. A. Hoque*
}

Department of Soil Science, Bangladesh Agricultural University, Mymensingh-2202

${ }^{1}$ Graduate School of Natural Science and Technology,

Okayama University, Okayama 700-8530, Japan

*Corresponding author: anamul71@yahoo.com

\section{Abstract}

Proline provides protection in plants against various abiotic stresses including salinity. The field experiment was conducted at the farmer's field of coastal area (Botiaghata, Khulna) to mitigate the adverse effects of salinity on growth and yield of maize by exogenous application of proline. In the experiment maize plants were treated with different concentrations of proline at seedling and/or vegetative stages. The plant growth parameters, grain and stover yields, nutrient uptake and $\mathrm{K}^{+} / \mathrm{Na}^{+}$ratio were recorded. All the yield contributing characters were significantly increased due to exogenous application of proline at different growth stages. Among the treatments, application of $100 \mathrm{mM}$ proline at seedling and vegetative stages offered the highest grain and stover yields $\left(5.7 \mathrm{t} \mathrm{ha}^{-1}\right.$ and $9.8 \mathrm{t} \mathrm{ha}^{-1}$, respectively) of maize which was followed by $100 \mathrm{mM}$ proline application at seedling stage where grain and stover yields were $5.7 \mathrm{t} \mathrm{ha}^{-1}$ and $9.7 \mathrm{t} / \mathrm{ha}$, respectively. However no significant differences were found between two treatments. Total N, P and S uptake $\left(203.66,23.24\right.$ and $23.14 \mathrm{~kg} \mathrm{ha}^{-1}$, respectively) were highest when the maize plants were treated with $100 \mathrm{mM}$ proline at seedling and vegetative stages. The highest $\mathrm{K}^{+} / \mathrm{Na}^{+}$ratio both in grain (12.92) and stover (5.57) was also observed in the same treatment. Therefore, it can be concluded that exogenous application of proline improves salinity tolerance in maize by increasing nutrient uptake and probably due to increasing antioxidant defense mechanisms.

Key words: $\mathrm{K}^{+} / \mathrm{Na}^{+}$ratio, Maize growth, Nutrient uptake, Salinity

\section{Introduction}

Soil salinity is a major concern to agriculture all over the world because it affects almost all plant functions. Millions of hectares of land throughout the world are too saline to produce economic crops, and more land is becoming non-productive each year due to salinity build up. Three hectares of arable lands are lost each minute because of soil salinization. More than $6 \%$ of the world's land and one third of the world's irrigated land are significantly affected by soil salinity (FAO, 2008). Agriculture is the single most important sector of Bangladesh's economy. Physiological stress in plants due to salinity is the major factor reducing crop yields in coastal areas of Bangladesh. Maize is one of the most important and widely grown food crops and third leading cereal crop in Bangladesh. Maize yield decreases under saline condition. Hence, to meet the increasing food demand it is essential to take necessary steps to increase the maize production in coastal areas. Plants are frequently exposed to several abiotic stresses during its growth and development. Salinity imposes both ionic toxicity and osmotic stress to plants, leading to nutritional disorder and oxidative stress. Salt stress causes increased uptake of $\mathrm{Na}^{+}$and $\mathrm{Cl}^{-}$, and decreased uptake of essential cations particularly $\mathrm{K}^{+}$(Khan et al., 2003). It has been reported that salt stress causes an increase in $\mathrm{Na}^{+}$to $\mathrm{K}^{+}$ratio in the cytosol (Zhu, 2003). Exogenously supply of proline reduced $\mathrm{Na}^{+}$ accumulation under salt stress (Ahmed et al., 2011). Maize can contribute significantly towards solving food problem and thereby play its gainful role in the agro-economy of the country. But satisfactory yield cannot be obtained due to salt stress in coastal areas of southern Bangladesh. Salt stress induces the accumulation of reactive oxygen species (ROS) including superoxide radical and hydrogen peroxide in plant cells (Banu et al., 2009, 2010). The excess production of ROS is toxic to plants and causes oxidative damage to cellular constituents, leading to cell death (Banu et al., 2009, 2010). Plants possess enzymatic and nonenzymatic antioxidant defense systems to protect their cells against the damaging effects of ROS. Proline has been shown to scavenge free radicals and ROS (Okuma et al., 2004; Banu et al., 2009, 2010). Several studies have shown that proline application effectively regulates osmotic potential and plays a vital role in sustaining plant growth under osmotic stress (Serraj and Sinclair, 2002; Ali et al., 2007; Ashraf and Foolad, 2007; Hoque et al., 2007). Exogenous application of proline would be one of the options to improve the crop productivity in salinity affected areas of Bangladesh. Increased levels of proline accumulated in plants correlate with improved salt tolerance (Okuma et al., 2004; Asharf and Foolad, 2007). Soil salinity management in salt-affected areas of Bangladesh in winter season to increase rice crop production, is a great concern in recent days. Thus current research should be emphasized on salinity management. Now-a-days, different salt tolerant varieties are developed for saline areas but yield potential is low. More research is necessary in order to increase crop yield in salt-affected areas. The present study is crucial for the improvement of salinity tolerance and economic crop production in the coastal areas of southern Bangladesh. Therefore, addition to management practices, exogenous application of proline is a novel approach for increasing yield of maize in coastal areas where salinity is a major concern. 


\section{Materials and Methods}

\section{Location and design of experiment}

To investigate the effects of exogenous proline on growth and yield of maize, the field experiment was conducted at the farmer's field of coastal area (Botiaghata, Khulna). The experiment was laid out in Randomized Complete Block Design with three replications.

\section{Soil}

Soil texture was silty clay loam, having $\mathrm{pH}$ 6.71, Electrical Conductivity $4.5 \mathrm{dSm}^{-1}$, exchangeable $\mathrm{Na} 2.21 \mathrm{meq} / 100 \mathrm{~g}$ soil, Organic Matter content $1.55 \%$.

\section{Crop and variety}

BARI Hybrid Maize-5 (BMH-5) was used as a test crop. Maize seeds were sown in the experimental plots maintaining appropriate spacing.

\section{Treatment combinations}

Proline at different concentrations was applied to maize plants at different growth stages. There were ten treatment combinations including control.

$\mathrm{T}_{0}=$ Control

$\mathrm{T}_{1}=25 \mathrm{mM}$ proline at seedling stage

$\mathrm{T}_{2}=25 \mathrm{mM}$ proline at vegetative stage

$\mathrm{T}_{3}=25 \mathrm{mM}$ proline at seedling and vegetative stages

$\mathrm{T}_{4}=50 \mathrm{mM}$ proline at seedling stage

$\mathrm{T}_{5}=50 \mathrm{mM}$ proline at vegetative stage

$\mathrm{T}_{6}=50 \mathrm{mM}$ proline at seedling and vegetative stages

$\mathrm{T}_{7}=100 \mathrm{mM}$ proline at seedling stage

$\mathrm{T}_{8}=100 \mathrm{mM}$ proline at vegetative stage

$\mathrm{T}_{9}=100 \mathrm{mM}$ proline at seedling and vegetative stages

\section{Management practices and proline application}

The recommended doses of urea, triple super phosphate, muriate of potash, gypsum and boric acid were applied in all the experimental plots. Irrigation was provided as and when necessary. Electrical conductivity of water used for irrigation was measured. The EC value of first and second irrigation water were 3.8 and $9.5 \mathrm{dS} \mathrm{m} \mathrm{m}^{-1}$. Plants were treated with different concentrations of proline at seedling and/or vegetative stages. Proline containing $0.1 \%$ Tween-20 as surfactant was applied at seedling and/or vegetative stages as foliar spray at a volume of $25 \mathrm{~mL}$ per plant per treatment. The intercultural operations, irrigation and other management practices were done as and when necessary.

\section{Crop harvesting and data collection}

The crop was harvested at full maturity. Grain and stover yields and plant growth parameters (plant height, plant weight, cob length, cob diameter, number of grains per cob, 100 grains weight etc.) were recorded. N, P, K, S and $\mathrm{Na}$ contents were measured from maize grain and stover samples.
Chemical analysis of plant samples

Grain and stover samples of maize were analyzed for $\mathrm{N}, \mathrm{P}, \mathrm{K}, \mathrm{S}$ and $\mathrm{Na}$ contents were determined following standard method as described by Khanam et al. (2001).

\section{Statistical analysis}

The data recorded on different parameters were analyzed statistically by statistical package MStatC. The significance of differences between mean values was compared by Duncan's Multiple Range Test (DMRT). Differences at $p<0.05$ were considered significant.

\section{Results and Discussion}

\section{Growth and yield components}

Salt stress caused a significant reduction in root growth of BARI Hybrid Maize-5. Table 1 shows that different growth parameters of maize plant showed significant differences due to exogenous application of proline under saline conditions. Different growth parameters like plant height, plant weight, cob length, cob diameter, number of grains per cob etc. were found lowest when the maize plants were not treated by proline in any growth stage. Application of proline found to be effective for ameliorating the salinity problem. Plant height showed insignificant difference between untreated plants and the plants which were treated with $25 \mathrm{mM}$ and $50 \mathrm{mM}$ proline in different growth stages but $100 \mathrm{mM}$ proline application showed significant difference in plant height. The growth parameters which were recorded found to be higher when the maize plants were treated with $100 \mathrm{mM}$ proline at seedling and vegetative stages than other treatments. Plant height, cob length and diameter and number of grains per cob increased significantly due to exogenous application of $100 \mathrm{mM}$ proline at both seedling and vegetative stages. Deivanai et al. (2011) conducted an experiment on rice to ameliorate the adverse effect of salinity and found that different growth components significantly decreased due to salinity but proline application increased the growth and yield components. Dogan (2011) also found that salinity decreased growth parameters in soybean and proline application ameliorates the adverse effect of salinity.

\section{Grain and stover yields}

Significant reductions in grain and stover yield of hybrid maize variety were observed in response to $\mathrm{NaCl}$ stress. Fig. 1 shows that soil salinity caused a significant decrease in the yield of maize. Significant difference was found in yield of maize 
based on spraying proline at different concentrations in different growth stages. Grain yield shows a significant increase on exogenous application of proline under salt stress. Grain yield decreased under salt stress but increased when proline application was done. Application of proline significantly increased the grain and stover yields of BARI Hybrid Maize-5 under saline conditions. The highest grain $\left(5.7 \mathrm{t} \mathrm{ha}^{-1}\right)$ and stover $\left(9.8 \mathrm{t} \mathrm{ha}^{-1}\right)$ yield of maize were obtained from the plots where $100 \mathrm{mM}$ proline was applied at seedling and vegetative stage which was statistically identical to $100 \mathrm{mM}$ proline at seedling stage and $50 \mathrm{mM}$ proline at seedling and vegetative stage.

Table 1. Effect of exogenous application of proline on growth and yield components of maize under saline conditions

\begin{tabular}{|c|c|c|c|c|c|c|}
\hline Treatments & $\begin{array}{c}\text { Plant } \\
\text { Height } \\
(\mathrm{cm})\end{array}$ & $\begin{array}{c}\text { Plant } \\
\text { Weight } \\
(\mathrm{gm})\end{array}$ & $\begin{array}{c}\text { Cob } \\
\text { length } \\
(\mathrm{cm})\end{array}$ & $\begin{array}{c}\text { Cob } \\
\text { Diameter } \\
(\mathrm{cm})\end{array}$ & $\begin{array}{c}\text { Number } \\
\text { of grains } \\
\text { per cob }\end{array}$ & $\begin{array}{c}\text { 100-grain } \\
\text { weight } \\
(\mathrm{gm})\end{array}$ \\
\hline T0 & $156.4 \mathrm{~d}$ & $215 \mathrm{c}$ & $17.1 \mathrm{e}$ & $12.2 \mathrm{c}$ & $372 \mathrm{de}$ & $24.1 \mathrm{~d}$ \\
\hline $\mathrm{T} 1$ & $157.1 \mathrm{~d}$ & $263.3 \mathrm{ab}$ & $17.4 \mathrm{cde}$ & $12.4 \mathrm{bc}$ & $365 \mathrm{e}$ & $24.5 \mathrm{~cd}$ \\
\hline $\mathrm{T} 2$ & $162.1 \mathrm{~cd}$ & $254.8 \mathrm{ab}$ & $17.3 \mathrm{de}$ & $12.3 \mathrm{bc}$ & $368 \mathrm{de}$ & $24.7 \mathrm{bcd}$ \\
\hline $\mathrm{T} 3$ & $161.6 \mathrm{~cd}$ & $267 \mathrm{ab}$ & $17.8 \mathrm{ab}$ & $12.5 \mathrm{~b}$ & $371 \mathrm{de}$ & $26.0 \mathrm{abc}$ \\
\hline $\mathrm{T} 4$ & $161.5 \mathrm{~cd}$ & $261 \mathrm{ab}$ & $17.4 \mathrm{cde}$ & $12.4 \mathrm{bc}$ & $398 \mathrm{~b}$ & $24.8 \mathrm{bc}$ \\
\hline T5 & $164.3 \mathrm{bcd}$ & $251.7 \mathrm{~b}$ & $17.5 \mathrm{cde}$ & $12.2 \mathrm{c}$ & $344 \mathrm{f}$ & $24.6 \mathrm{~cd}$ \\
\hline $\mathrm{T} 6$ & $164.5 \mathrm{bcd}$ & $251.3 \mathrm{~b}$ & $17.8 \mathrm{ab}$ & $12.2 \mathrm{c}$ & $340 \mathrm{f}$ & $25.0 \mathrm{abc}$ \\
\hline $\mathrm{T} 7$ & $164.7 \mathrm{bcd}$ & $266 \mathrm{ab}$ & $17.7 \mathrm{abc}$ & $12.5 \mathrm{~b}$ & $378 \mathrm{c}$ & $26.1 \mathrm{abc}$ \\
\hline T8 & $168.7 \mathrm{abc}$ & $273.7 \mathrm{a}$ & $18.0 \mathrm{a}$ & $12.3 \mathrm{bc}$ & $383 \mathrm{~cd}$ & $26.2 \mathrm{abc}$ \\
\hline $\mathrm{T} 9$ & $177.1 \mathrm{a}$ & $272 \mathrm{a}$ & $18.1 \mathrm{a}$ & $13.0 \mathrm{a}$ & $409 \mathrm{a}$ & $26.6 \mathrm{a}$ \\
\hline $\mathrm{SE}( \pm)$ & 3.15 & 5.93 & 0.133 & 0.069 & 3.47 & 0.563 \\
\hline
\end{tabular}

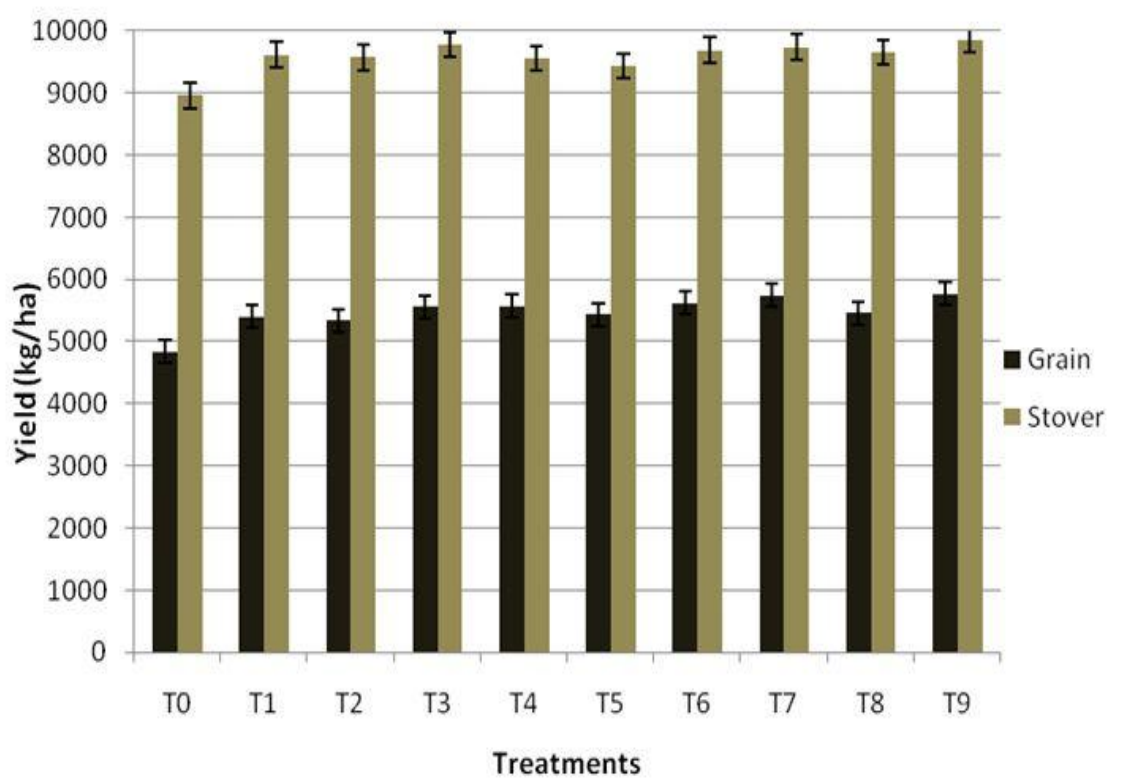

Fig. 1. Grain and stover yields of maize influenced by exogenous proline under saline conditions

The lowest grain and stover yield $\left(4.8 \mathrm{t} \mathrm{ha}^{-1}\right.$ and 8.9 $\mathrm{t} \mathrm{ha}^{-1}$, respectively) of maize was recorded from untreated control. Islam et al. (2011) on hybrid rice also reported that grain yields decreased by the salinity. Ali et al. (2004) also found the similar result on grain yield of rice. Devar et al., 2013 found that grain yield and stover yield significantly decrease under salt stress and proline application helps to ameliorate the salinity problem. Miah et al. (1992) on two rice varieties also found that salinity decreased stover yield of rice. Dogan (2011) reported that grain and stover yield reduced in maize due to salt stress.

\section{Total nutrient uptake}

We investigated whether exogenous proline influenced nutrient uptake by maize under salt stress. To investigate the nutrient uptake by maize, we measured nutrient content in maize stover and grain. Salt stress caused reductions in nutrient (NPS) uptake by stover and grain of both maize varieties. On the other hand, application of proline increased nutrient (NPS) uptake by maize under saline conditions. Exogenous proline resulted in an increase in nutrient uptake in response to salt stress. Total N (203.66 kg ha $\left.{ }^{-1}\right), \mathrm{P}\left(23.24 \mathrm{~kg} \mathrm{ha}^{-1}\right)$ and S $\left(23.14 \mathrm{~kg} \mathrm{ha}^{-1}\right)$ uptake was significantly higher at 
$100 \mathrm{mM}$ proline at seedling and vegetative stages while the lowest was recorded from untreated control and it was $136.54 \mathrm{~kg} \mathrm{ha}^{-1} \mathrm{~N}, 16.6 \mathrm{~kg} \mathrm{ha}^{-1} \mathrm{P}$ and $18.7 \mathrm{~kg} \mathrm{ha}^{-1} \mathrm{~S}$ (Table 2). Exogenous application of proline has been shown to increase nutrient uptake (NPS) and reduces adverse effects of salt stress in maize (Ali et al., 2008). Hamed et al. 1994 on maize also reported that total nutrient uptake was decreased due to salinity and increased due to exogenous application of proline. Momayezi et al. (2010) also found that salt stress decreased the total nutrient uptake by rice. Kumar and Sharma (1989) reported that nutrient uptake in mungbean was reduced due to salinity and it can be increased by exogenous application of proline.

Table 2. Effect of exogenous application of proline on nutrient (NPS) uptake of maize under saline conditions

\begin{tabular}{|c|c|c|c|}
\hline Treatments & Total N uptake $(\mathrm{kg} / \mathrm{ha})$ & Total P uptake $(\mathrm{kg} / \mathrm{ha})$ & Total Suptake $(\mathrm{kg} / \mathrm{ha})$ \\
\hline T0 & $136.54 \mathrm{e}$ & $16.67 \mathrm{f}$ & $18.74 \mathrm{c}$ \\
\hline T1 & $179.32 \mathrm{~d}$ & $19.27 \mathrm{de}$ & $21.26 \mathrm{~b}$ \\
\hline T2 & $176.30 \mathrm{~d}$ & $18.65 \mathrm{e}$ & $21.12 \mathrm{~b}$ \\
\hline T3 & $194.80 \mathrm{~b}$ & $20.06 \mathrm{~cd}$ & $21.60 \mathrm{~b}$ \\
\hline T4 & $188.30 \mathrm{c}$ & $19.49 \mathrm{de}$ & $21.70 \mathrm{~b}$ \\
\hline T5 & $180.60 \mathrm{~d}$ & $20.61 \mathrm{~cd}$ & $21.57 \mathrm{~b}$ \\
\hline T6 & $196.01 \mathrm{~b}$ & $21.90 \mathrm{bc}$ & $22.43 \mathrm{ab}$ \\
\hline T7 & $195.22 \mathrm{~b}$ & $22.52 \mathrm{ab}$ & $22.95 \mathrm{ab}$ \\
\hline T8 & $183.32 \mathrm{~cd}$ & $21.85 \mathrm{bc}$ & $21.57 \mathrm{~b}$ \\
\hline T9 & $203.66 \mathrm{a}$ & $23.24 \mathrm{a}$ & 1.12 \\
\hline SE $( \pm)$ & 4.42 & 1.23 & \\
\hline
\end{tabular}

\section{$\mathrm{K}^{+} / \mathrm{Na}^{+}$ratio}

Potassium (K) and Sodium (Na) are most important element for the plant to survive in salt stress. Salt tolerance is directly associated with $\mathrm{K}$ contents because of its involvement in osmotic regulation and competition with $\mathrm{Na}$. Plant salt tolerance requires

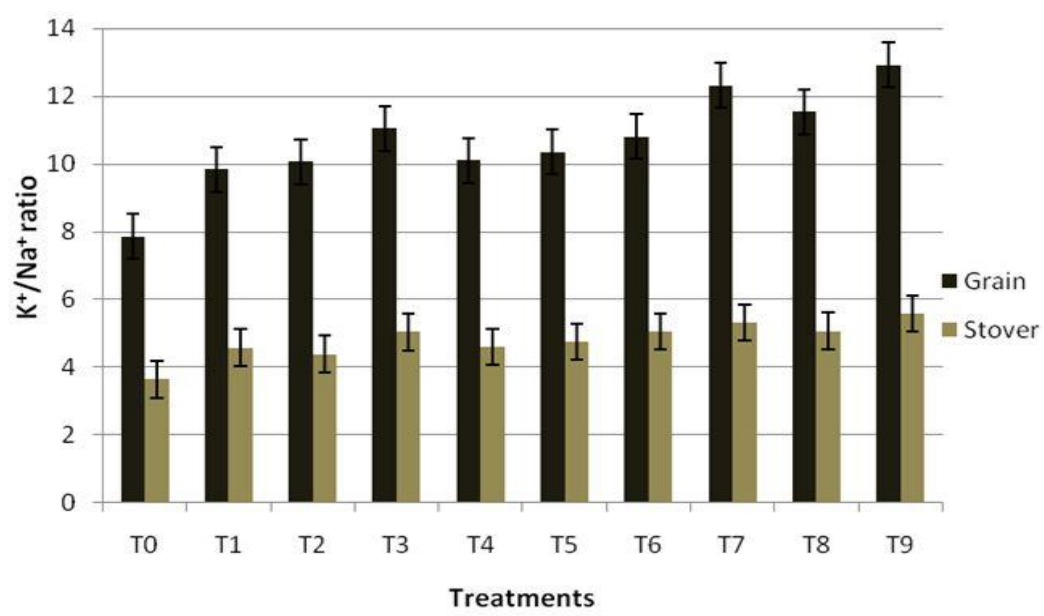

Fig. 2. $\mathrm{K}^{+} / \mathrm{Na}^{+}$ratio in grain and stover of maize influenced by exogenous proline under saline conditions

not only adaptation to $\mathrm{Na}^{+}$toxicity but also the acquisition of abundant $\mathrm{K}^{+}$whose uptake by the plant cell is affected by high external $\mathrm{Na}^{+}$ concentrations. Soil salinity significantly decreased $\mathrm{K}^{+} / \mathrm{Na}^{+}$ratio in both grain and stover samples. Foliar application of proline resulted in a significant increase in $\mathrm{K}^{+} / \mathrm{Na}^{+}$ratio in maize plants. In grain, the highest $\mathrm{K}^{+} / \mathrm{Na}^{+}$ratio (12.92) was found when the maize plants were treated with $100 \mathrm{mM}$ proline at seedling and vegetative stages which was statistically identical to $100 \mathrm{mM}$ proline at seedling stage and $100 \mathrm{mM}$ proline at vegetative stage. In stover, the highest $\mathrm{K}^{+} / \mathrm{Na}^{+}$ratio (5.57) was found at same treatment and statistically similar to $\mathrm{T} 7$ and T8 including T6 $(50 \mathrm{mM}$ proline at seedling and vegetative stages). The lowest $\mathrm{K}^{+} / \mathrm{Na}^{+}$ratio (7.85 and 3.64, respectively) both in grain and stover was found in untreated plants (Fig. 2). There are evidences that exogenously supplied proline reduced $\mathrm{Na}^{+}$accumulation under salt stress and increases $\mathrm{K}^{+} / \mathrm{Na}^{+}$ratio (Zhu, 2003). Ahmed et al. (2011) also conducted an experiment on young olive and also found that exogenous application of proline increases $\mathrm{K}^{+} / \mathrm{Na}^{+}$ratio significantly. Haq et al. (2009) on seven rice varieties, Nounjan et al. (2012) on Thai aromatic rice and Miah et al. (1992) on two rice varieties at different salinity level also found that salinity decreased $\mathrm{K}^{+} / \mathrm{Na}^{+}$ratio and proline application increases the $\mathrm{K}^{+} / \mathrm{Na}^{+}$ratio in rice. Devar et al., 2013 conducted an experiment on maize and concluded that $\mathrm{K}^{+} / \mathrm{Na}^{+}$ratio significantly decreases under salt stress. 


\section{Conclusions}

This study indicates that salinity causes significant yield loss of maize and that could be minimized by application of proline during both seedling and vegetative growth stages. Crop cultivation in saline areas might be profitable with proline application. Crop plants with over accumulating proline confer tolerance to salinity.

\section{References}

Ahmed, C. B.; Magdich, S.; Rouina, B. B.; Sensoy, S.; Boukhris, M. and Abdullah, F. B. 2011. Exogenous proline effects on water relations and ions contents in leaves and roots of young olive. Amino Acids, 40:565-573.

Ali, Y.; Aslam, Z.; Ashraf, M. Y. Tahir, G. R. 2004. Effect of salinity on chlorophyll concentration, leaf area, yield and yield components of rice genotypes grown under saline environment. International Journal of Environmental Science and Technology, 1(3): 221-225.

Ali, Q.; Ashraf, M. and Athar, H. R. 2007. Exogenously applied proline at different growth stages enhances growth of two maize cultivars grown under water deficit conditions. Pakistan Journal of Botany, 39(4):1133-1144.

Ali, Q.; Ashraf, M.; Shahbaz, M. and Humera, H. 2008. Ameliorative effect of foliar applied proline on nutrient uptake in water stressed maize (Zea mays L.) plants. Pakistan Journal of Botany, 40: 211-219.

Ashraf, M. and Foolad, M. R. 2007. Roles of glycinebetaine and proline in improving plant abiotic stress resistance. Environmental and Experimental Botany, 59:206-216

Banu, M. N. A.; Hoque, M. A.; Sugimoto, W. M.; Islam, M. M.; Uraji, M.; Mastuoka, K.; Nakamura, Y.; Shimoishi, Y. and Murata, Y. 2010. Proline and glycinebetaine ameliorated $\mathrm{NaCl}$ stress via scavenging of hydrogen peroxide and methylglyoxal but not superoxide or nitric oxide in tobacco cultured cells. Bioscience, Biotechnology and Biochemistry, 10: 2043-2049.

Banu, M. N. A.; Hoque, M. A.; Sugimoto, W.; M.; Mastuoka, K.; Nakamura, Y.; Shimoishi, Y. and Murata, Y. 2009. Proline and glycinebetaine induce antioxidant defense gene expression and suppress cell death in cultured tobacco cells under salt stress. Journal of Plant Physiology, 166:146-156.

\section{Acknowledgements}

This work was supported by a grant from the Bangladesh Agricultural Research Council.

Davar, M.; Jafar, A.; Marefat, G.; Mohsen, H. and Ali, K. 2013. Is salinity tolerance related to $\mathrm{Na}$ accumulation in maize cultivars (Zea mays L.) Life Science Journal, 10(1s):72-75

Deivanai, S.; Xavier, R.; Vinod, V.; Timalata, K. and Lim, O. F. 2011. Role of exogenous proline in ameliorating salt stress at early stage in two rice cultivars. Journal of Stress Physiologyand Biochemistry, 7(4):157-174.

Dogan, M. 2011. Antioxidative and proline potentials as a protective mechanism in soybean plants under salinity stress. African Journal of Biotechnology, 10(32):5972-5978.

FAO (Food and Agricultural Organization). 2008. Land and Plant Nutrition Management Service. http://www.fao.org/ag/agl/agll /spush

Haq, T. U.; Akhtar, J.; Nawaz, S. and Ahmad, R. 2009. Morpho-physiological response of rice (Oryza sativa L.) varieties to salinity stress. Pakistan Journal of Botany, 41(6):2943-2956.

Hamed, A. A. and Wakeel, S. A. M. A. 1994. Physiological response of Zea mays exposed to salinity and to exogenous proline. Egypt Journal of Botany, 34:93-105.

Hoque, M. A.; Okuma, E. Banu, M. N. A.; Nakamura, Y. Shimoishi, Y. and Murata, N. 2007. Exogenous proline mitigates the detrimental effects of salt stress more than exogenous betaine by increasing antioxidant enzyme activities. Journal of Plant Physiology, 164:553- 561.

Islam, M. T.; Sharma, P. C.; Gautam, R. K.; Singh, D.; Singh, S.; Panesar, B. and Ali, S. 2011. Salt tolerance in parental lines of rice hybrids through physiological attributes molecular markers. International Journal of Experimental Agriculture, 2(1):1-7.

Khanam, M. Rahman, M. M.; Islam, M. R. and Islam, M. R. 2001. Effect of manures and fertilizers on the growth and yield of BRRI dhan 30. Pakistan Journal of Biological Science, 4: 172-174. 
Khan, A. A.; Rao, S. A. and McNeilly, T. 2003. Assessment of salinity tolerance based upon seedling root growth response function in maize (Zea mays L.). Euphetica, 131:81-89.

Kumar, V. and Sharma, D. R. 1989. Effect of exogenous proline on growth and ion content in $\mathrm{NaCl}$ stressed and non stressed cells of mungbean, Vignaradiata var. radiata. Indian Journal of Experimental Biology, 27:813-815.

Miah, M. M. A.; Panaullah, G. M.; Rahman, M. S. and Ishaque, M. 1992. Effect of soil salinity and phosphorus on the growth yield and mineral nutrition of rice. Bangladesh Rice Journal, 3 (1\&2):1-5.

Momayezi, M. R.; Zaharah, A. R.; Hanafi, M. M. and Ismail, M. R. 2010. Effect of chloride and sulfate salinity on nutrient uptake in Iranian rice (Oryza sativa L.). $19^{\text {th }}$ World Congress of Soil Science, Soil solutions for a changing world, 1-6 August 2010, Brisbane, Australia. pp: 36-39.
Nounjan, N.; Nghia, P. T. and Theerakulpisut, P. 2012. Exogenous proline and trehalose promote recovery of rice seedlings from saltstress and differentially modulate antioxidant enzymes and expression of related genes. Journal of Plant Physiology, 169(6):596-604.

Okuma, E.; Murakami, Y.; Shimoishi, Y.; Tada, M.; Murata, Y. 2004. Effects of exogenous application of proline and betaine on the growth of tobacco cultured cells under saline conditions. Journal of Soil Science and Plant Nutrition, 50:1301-1305.

Serraj, R. and Sinclair, T. R. 2002. Osomlyte accumulation: can it really help increase crop yield under drought conditions. Plant Cell Environment, 25:333-341.

Zeng, L. and Shannon, M. C. 2000. Salinity effects on seedling growth and yield components of rice. Crop Science, 40(4):996-1003.

Zhu, J. K. 2003. Regulation of ion homeostasis under salt stress. Current Opinion in Plant Biology, 6:441-445. 